Tózsa István-Sallai János

\title{
Geostratégia az EU délkeleti kapujában
}

\section{Geostrategy at the EU's South-Eastern Gate}

\section{Összefoglalás}

A tanulmány a 2015 óta felerôsödött, Európába irányuló ázsiai és afrikai migráció geostratégiai okait mutatja be. Térképekkel és múszaki határvédelmi adatokkal illusztrálva ismerteti a magyar kormány válaszintézkedéseit, annak hatásait, különös tekintettel az Európai Unió délkeleti határszakaszára és a schengeni határvédelemre. A tanulmány rávilágít az egész Európát érintô globális folyamat geostratégiai jelentôségére.

Journal of Economic Literature (JEL) kódok: F22, J61, O15

Kulcsszavak: migráció, határvédelem, Európai Unió, schengeni övezet, geostratégia

\section{Summary}

The study presents the geostrategic causes of Asian and African migration to Europe, which has increased considerably since 2015 . Illustrated with maps and technical border protection data, it presents the Hungarian government's response actions and their effects, with particular regard to the south-eastern border region of the European Union and the Schengen border region. The study highlights the geostrategic significance of the global process affecting Europe.

Journal of Economic Literature (JEL) codes: F22, J61, O15

Keywords: migration, border protection, European Union, Schengen area, geostrategy

Tózsa IsTván intézetvezetô egyetemi tanár, Nemzeti Közszolgálati Egyetem, Közszervezési és Közigazgatástani Intézet (Tozsa.Istvan@uni-nke.hu), SAllai János tanszékvezetô egyetemi tanár, Nemzeti Közszolgálati Egyetem, Rendészetelméleti és Történeti Tanszék (Sallai.Janos@uni-nke.hu). 


\section{BEVEZETÉS}

Az Európai Unió fejlettebb régiói felé irányuló tömeges ázsiai és afrikai bevándorlással kapcsolatban a magyar kormány 2015-ben bevezetett intézkedései az elmúlt években heves politikai vitákat generáltak Európa-szerte. Hogyan módosult a nyugat-balkáni migrációs útvonal a magyar határvédelmi rendszer életbelépése következtében? Milyen globális geostratégiai környezetben zajlik a bevándorlás? Milyen következményei vannak az Unió délkeleti határzónájára? A tanulmány ezekre a kérdésekre igyekszik választ adni.

Az Európai Unió gazdasági motorja 2014-ben vitathatatlanul Németország volt, amely gazdasági erejét tekintve egész Európában vezetó helyet foglalt el (1. ábra).

\section{1. ábra: Európa elsô 13 legerôsebb gazdaságú országa 2014-ben (GDP, Mrd USD)}

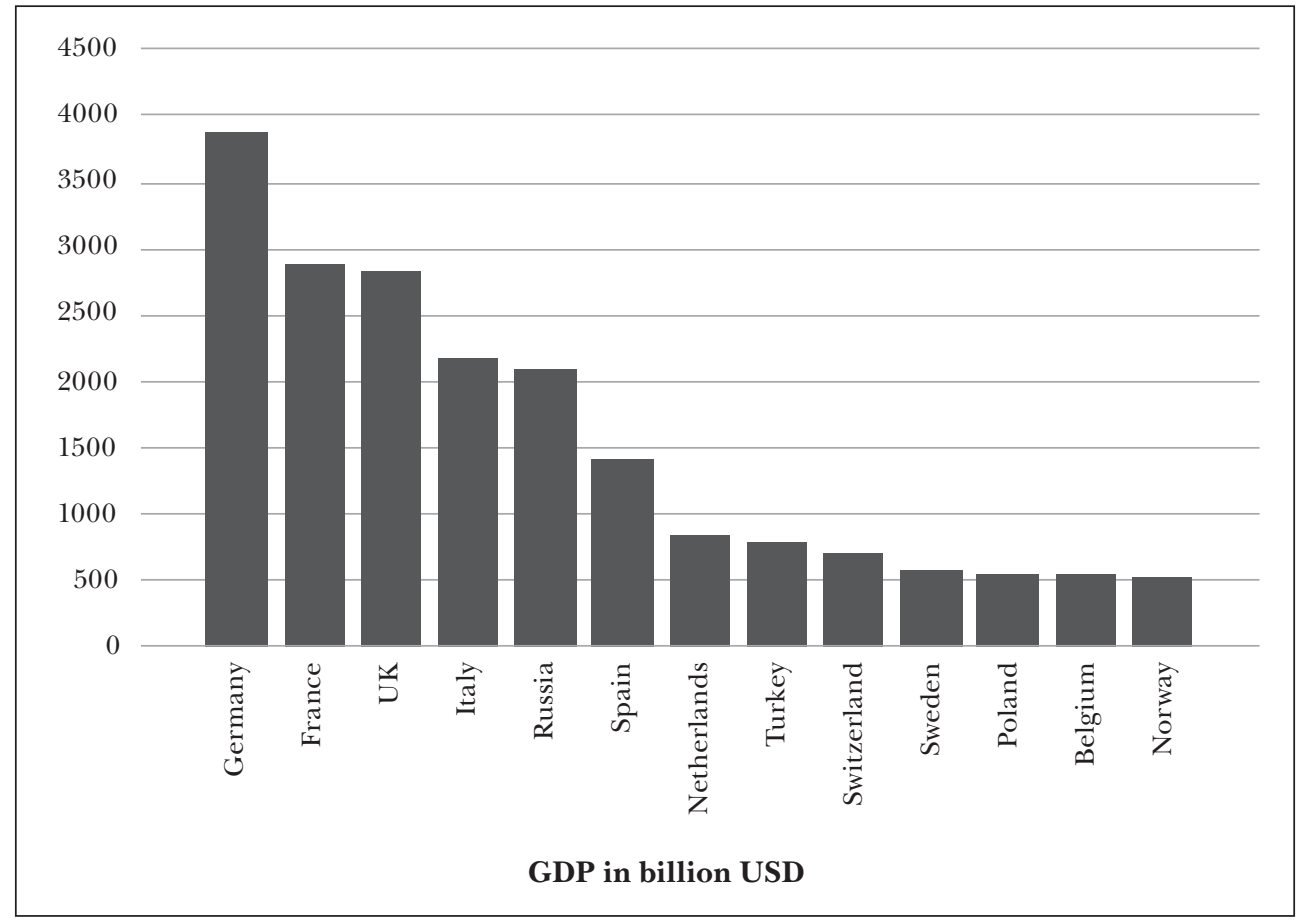

Forrás: www.knomea.com (IMF, WB, CIA), 2014

2014 volt az elsó év, amikor az EU-28 GDP-je (18 437 Mrd USD) meghaladta az addig versenytárs nélküli globális szuperhatalomét, az USA-ét (17 528 Mrd USD) (2. ábra).

Különös véletlen, hogy az amerikai „demokráciaexporttal” életre hívott arab tavasz következtében összeomlott líbiai és szíriai diktatórikus rendszerek helyén maradt polgárháborús, gyenge államhatalmú régiókból, valamint rajtuk keresztül, továbbá Pakisztánból, Irakból és Afganisztánból 2015-ben hirtelen felerôsödött Európa irányába a migráció. A polgárháborúk és a globális felmelegedés gazdaságromboló hatására az 
2. ábra: A világ elsố tíz gazdasági nagyhatalma 2014-ben (GDP Mrd USD)

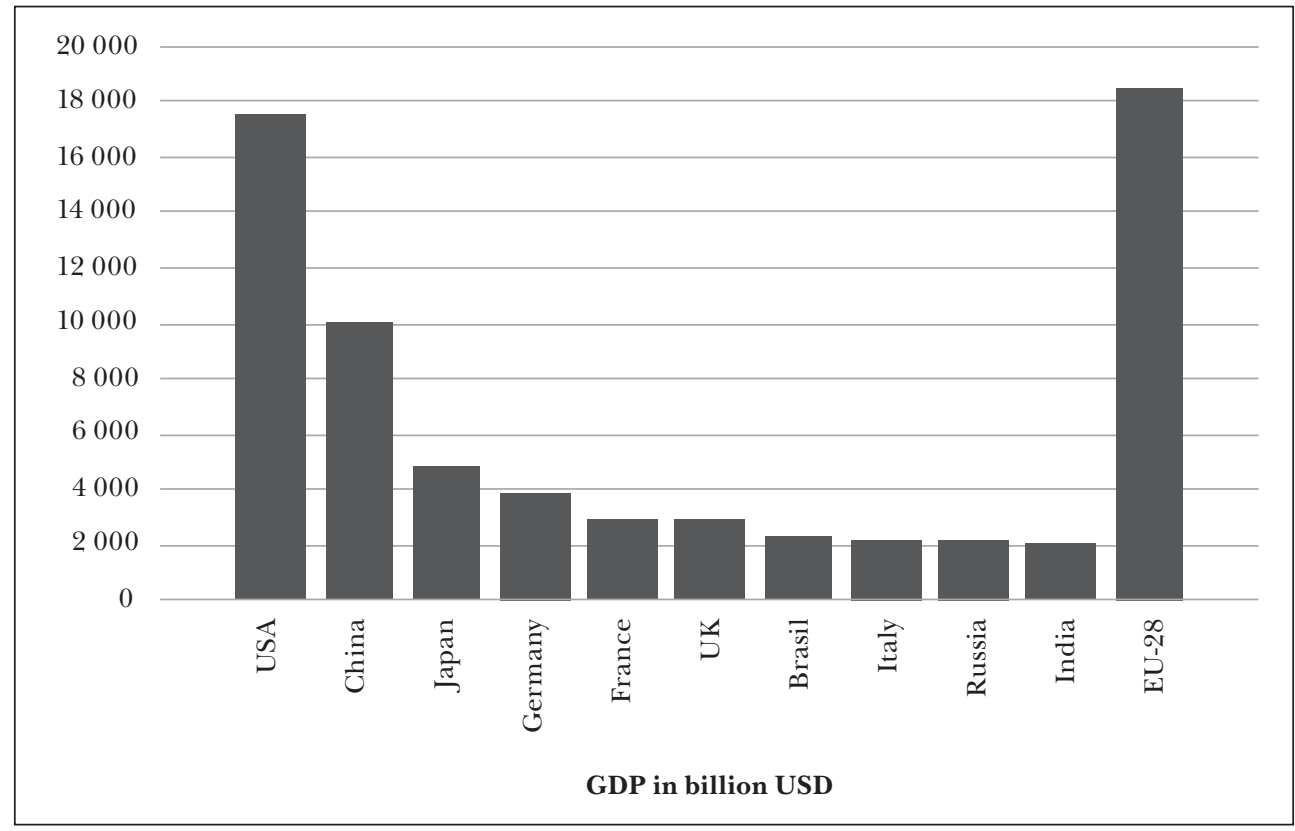

Forrás: www.knomea.com (IMF, WB, CIA), 2014

ázsiai és afrikai régiókból tömegek keltek-kelnek útra a jóléti Európa, azon belül elsôsorban éppen Németország (és Németországon keresztül Skandinávia) felé, a jobb megélhetés reményében.

Az afrikai és ázsiai szegénységi küszöb alatt élook száma egy hatalmas embertömegként tornyosul a magasabb életszínvonalon élô, de kisebb számú európai országok társadalmai fölé (3. ábra).

A modern kori népvándorlás tehát - jelen tanulmány szerzóinek véleménye szerint - egész Európát, de elsôsorban az Európai Uniót fenyegeti. A migránsok fiatal életkora, neme (a késôbbi családegyesítés reményében érkezó férfiak) és tradicionális nagycsaládos modelljük egyrészt a demográfiai átrendezôdés veszélyét jelentik az elöregedô európai társadalmakra. Szociális ellátásuk biztosítása is kettôs veszélyt rejt magában. Egyrészt belsố társadalmi feszültséget kelt, különösen a közép-európai uniós tagországok esetében, ahol a migránsok támogatási összege (havi ezer euró fejenként) jóval meghaladja az átlagjövedelmet (ennyi például egy egyetemi tanár havi nettó átlagjövedelme is). Másrészt a bevándorlók ellátásának extraterhe a tagországok hitelfelvételét, adósságállományát növeli. Mindez az állami kölcsönöket nyújtó nemzetközi pénzvilág érdekében áll. A nemzetközi adósságspirálba került országok nemzetállami törekvései szükségszerúen gyengülnek.

Kulturális értelemben a migránsok tömeges megjelenése az eltérô vallási, erkölcsi értékrend miatt megnehezíti mind a munkavállalást, mind a társadalmi integrációt. Gondoljunk itt a bevándorlók körében a nôk alárendelt szerepére, az eltérô gazdasági 
3. ábra: Asszociatív térkép, amely a világtérképen torzítással emeli ki a lakosság számát az egyes országokban és kontinenseken.

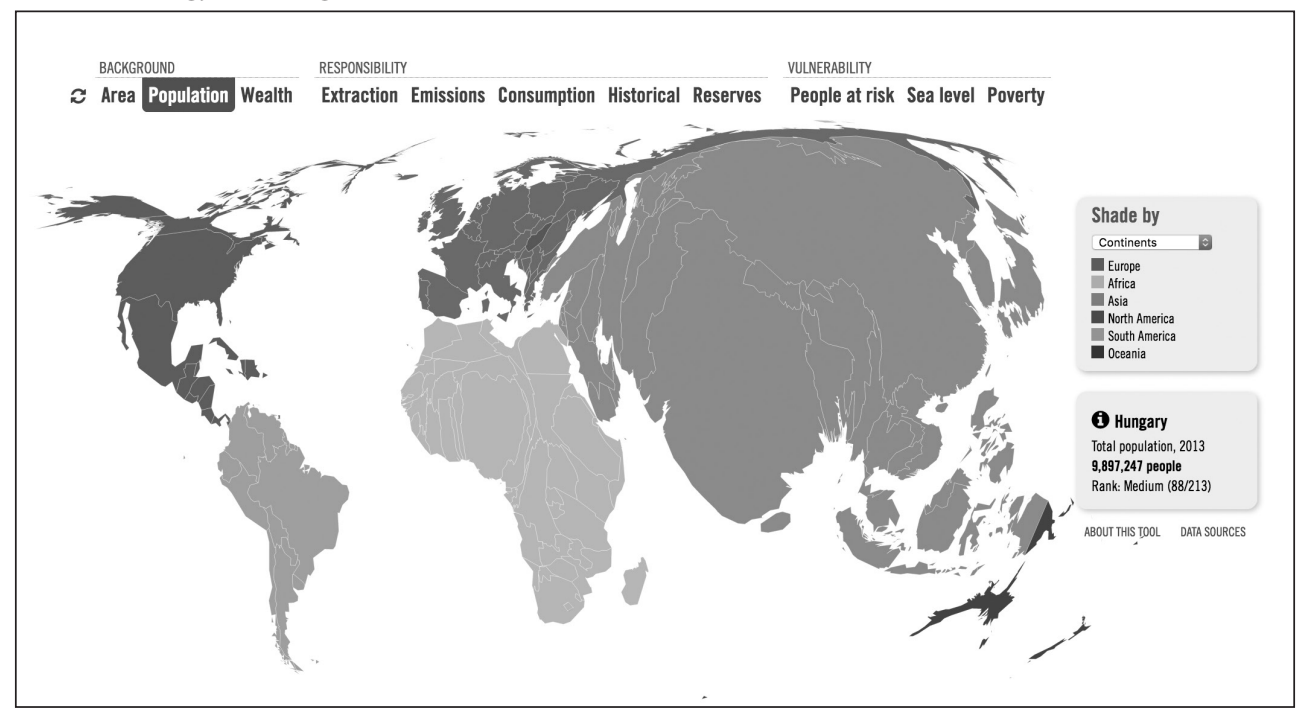

Forrás: http://nagysandor.eu/TED/Greg_Asner.html

etikára, az eltérố munkamorálra, a nyelvismeret hiányára és a keresztény „hitetlenek” elleni szent háborúra, amely a befogadó országban a helyhez kötôdố identitás hiányában még a második generációs bevándorlók fiataljait is esetlegesen a terrorizmus felé sodorhatja (4. ábra).

\section{CUI PRODEST?}

Az Európai Unió vezetôsége és az ENSZ támogatja a migrációt, annak várható hatásai (4. ábra) ellenére. Felmerül a geostratégiai kérdés, hogy ez kinek áll érdekében? Nyilvánvaló, hogy az uniós tagországoknak a bevándorlók ellátásával járó szociális-gazdasági megterhelése Németország esetében, a német gazdaság lelassításával az amerikai külgazdasági erôk alapvetô érdeke. Így, különösen az Egyesült Királyság Unióból való kilépésével (Brexit) az Unió már nem jelent közvetlen gazdasági kihívást az USA globális szupergazdaságának. A többi tagállam és különösen a posztszocialista, gazdaságilag gyengébb közép-európaiak újabb hitelfelvételre kényszerülnének, hogy a bevándorlók ellátásával kapcsolatos kötelezettségüket teljesíthessék. Ez szintén az amerikai bázisú nemzetközi pénzvilág érdekét szolgálja, s egyúttal konjunkturális hatást is gerjeszt a világgazdasági válság elodázására. De vajon mi készteti a német politikai vezetôket a migráció támogatására?

Az európai uniós német gazdasági hegemónia akkor tud teret nyerni - a két világháború után ezúttal békés úton -, ha a tagállamok a legerôsebb uniós gazdaság javára lemondanának az önálló külügyrôl, és erôteljesen megindulnának az európai föderáció irányába. Ennek útjában az igen erôs kultúrával rendelkezô európai, keresztény 


\section{4. ábra: Az Európába irányuló ázsiai-afrikai migráció komplex társadalmi} hatásmechanizmusa a befogadó országokban

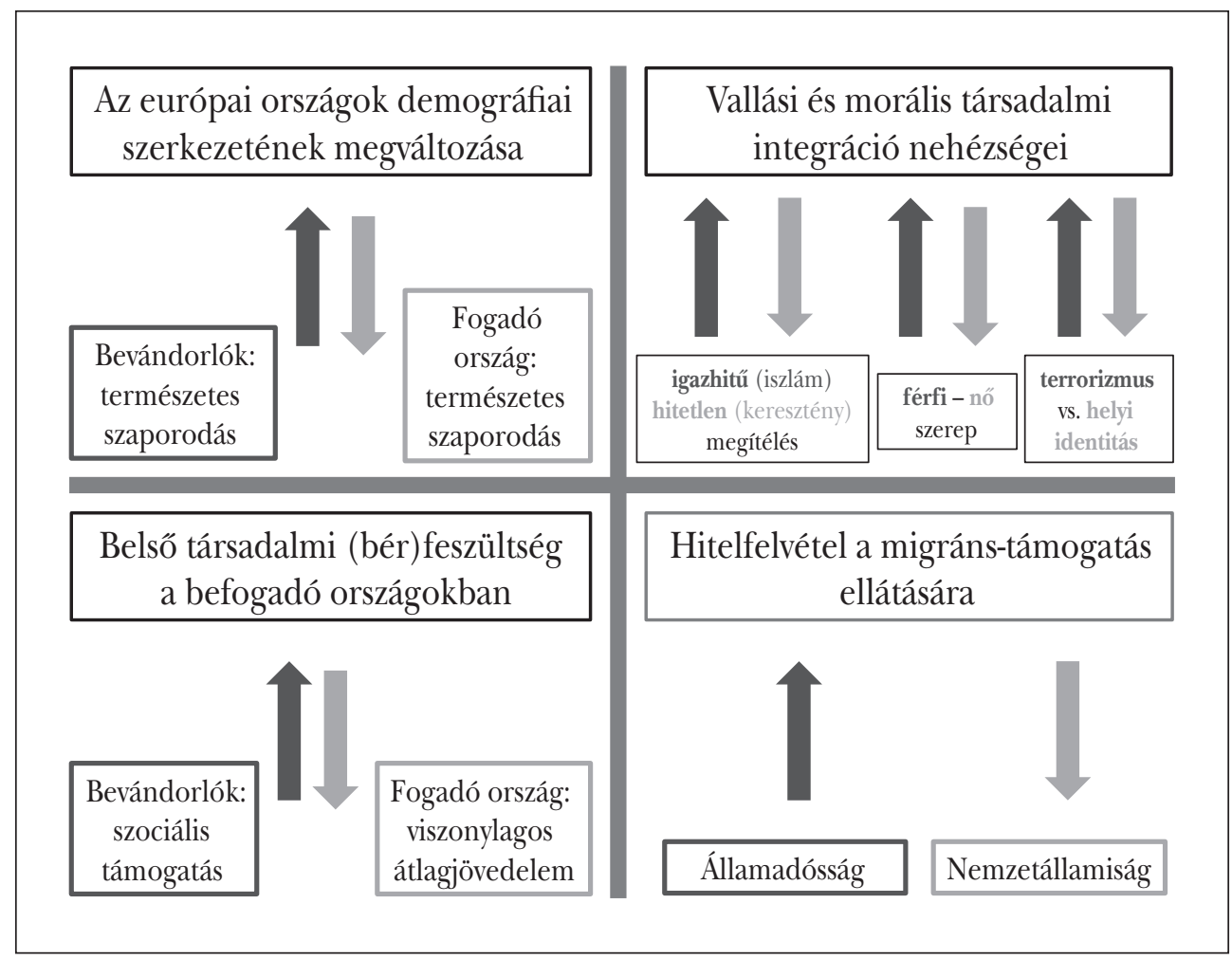

Forrás: Saját szerkesztés

nemzetállamiság eszméje áll. A nemzetállamiságot a nemzetközi hitelfelvételekkel, a belsô demográfiai és vallási összetételük megváltoztatásával lehet gyengíteni úgy, hogy a bevándorló, virulens kultúra minden uniós országban lehetôleg homogén (iszlám) legyen. A német politikai vezetés szerint néhány millió migráns németországi befogadása és eltartása - valamint néhány további millió migráns rákényszerítése a tagállamokra - az ára annak, hogy Németország az Európai Unió egyedüli és irányító ereje legyen nemcsak gazdasági, de szociális téren is. A német Európai Unió - különösen, ha a franciák is kilépnek egy francia mediterrán és észak-afrikai unió létrehozásának céljával - akkor lehet az Amerikai Egyesült Államok méltó gazdasági partnere és kihívója, ha gazdaságpolitikailag egységes föderációvá válik, olyan neoliberális „nemzetállamokkal”, amelyek megelégednek a kulturális autonómiával.

\section{MAgYARORSZÁg GEOSTRATÉGIAI HELYZETE}

Jelenleg az Európai Unió 28 országa közül 6 ország (Egyesült Királyság, Írország és Ciprus, valamint a legkésôbb csatlakozott Románia, Bulgária és Horvátország) nem 
tagja a schengeni határôrizeti övezetnek. A nem uniós tagállamok közül viszont Svájc, Norvégia és Izland tagja Schengennek. A schengeni egyezmény hatálya alá tartozó országok között a munkaerô és a tôke szabad áramlása az országok közötti határellenőrzés nélkül valósul meg.

Ha az 5. ábrát tekintjük, geostratégiai vonatkozásban azt látjuk, hogy az Unió meszsze legsebezhetőbb pontja a görög szigetvilág, amely nincs szárazföldi összeköttetésben egyetlen schengeni országgal sem, és a szigetek gyakorlatilag megvédhetetlenek határórizeti szempontból. 2015-ben valóban itt indult meg a tömeges migráció Németország felé Törökország felól. Mivel Görögország meg sem próbálta betartani a számára betarthatatlan dublini egyezményt a bevándorlók kezeléséról, regisztrációjáról, elosztásáról, a migránsok szabadon vonultak tovább Macedónián és Szerbián át Magyarország, Ausztria, Németország irányába. Ezzel egyidejúleg a közigazgatási káoszba süllyedt Líbián át, tengeri útvonalon, olaszországi belépéssel megindult a tömeges népvándorlás Afrika szárazsággal és globális felmelegedéssel sújtott Száhel övezetéből. Olaszország ugyan megpróbálja kezelni a bevándorlást, de gátat vetni nem tud neki, és egyre nagyobb terhet jelent számára.

Mivel addig, amíg az Unió nem kényszeríti a tagállamait a menekültek kötelezô és felsố határ nélküli befogadására, a migránsok elsôdleges desztinációja a „tejjel-mézzel folyó Kánaán,” Németország, illetve a skandináv országok és az Egyesült Királyság. Ez az Unióban Görögország felôl északnyugati, Olaszország felól északi vándorlási útvonalat jelent. Ezért egyelőre Románia és Bulgária, valamint Szlovákia, Csehország, Lengyelország, Litvánia, Lettország és Észtország nem képez migránsdesztinációt. A schengeni zónából is csak Magyarországot mint átjárót, tranzitországot érinti Ausztria és Németország felé. Az 5. ábra térképen látható, hogy a két uniós, de nem schengeni tag, Románia és Horvátország között egy korridor „kínálja magát” Magyarország felé, ahol a további szabad és kontroll nélküli mozgás reményében tudnak belépni a Németország felé tartó migránsok az Unióba. Amikor Magyarország a határvédelmi rendszerét életbe léptette, hogy megfeleljen az uniós és schengeni kötelezettségvállalásainak, ezt a török-görög irányból érkezô migránsáradatot nyugatabbra kényszerítette, hogy azok Horvátországon át próbáljanak Szlovéniába - és így a schengeni övezetbe - jutni.

Látni kell azonban, hogy ha az Európai Unió vezetői, a jelenlegi szándékuk szerint, kötelezôvé teszik minden tagországnak a bevándorlók befogadását, Románia, Bulgária és Horvátország ugyanúgy ki lesz téve a befogadás teljesítésével járó, belsô társadalmi feszültségeknek. A migránsok havi ezereurós járandóságának vásárlóereje ugyanis ezekben a közép-európai országokban magasabb, mint Nyugat-Európában. Azt az érvelést, miszerint a bevándorlókra mint munkaerôre lenne szükség Európában, az eddigi felmérések nem igazolták, mert a migránsoknak csak kis része állt munkába egy év alatt. ${ }^{1}$

\section{SGHENGENRE HANGOLVA}

Magyarország a rendszerváltás után az euroatlanti irányba fordult, és felkészült a NATO-, EU-, Schengen-csatlakozásra (Sallai, 2001). Közben több migrációs hullám érte el Magyarország határait, így 1989-ben román és NDK-invázió, majd a 90-es években 


\section{5. ábra: Az Európai Unió és határôrizeti rendszerének (schengeni zóna) országai}

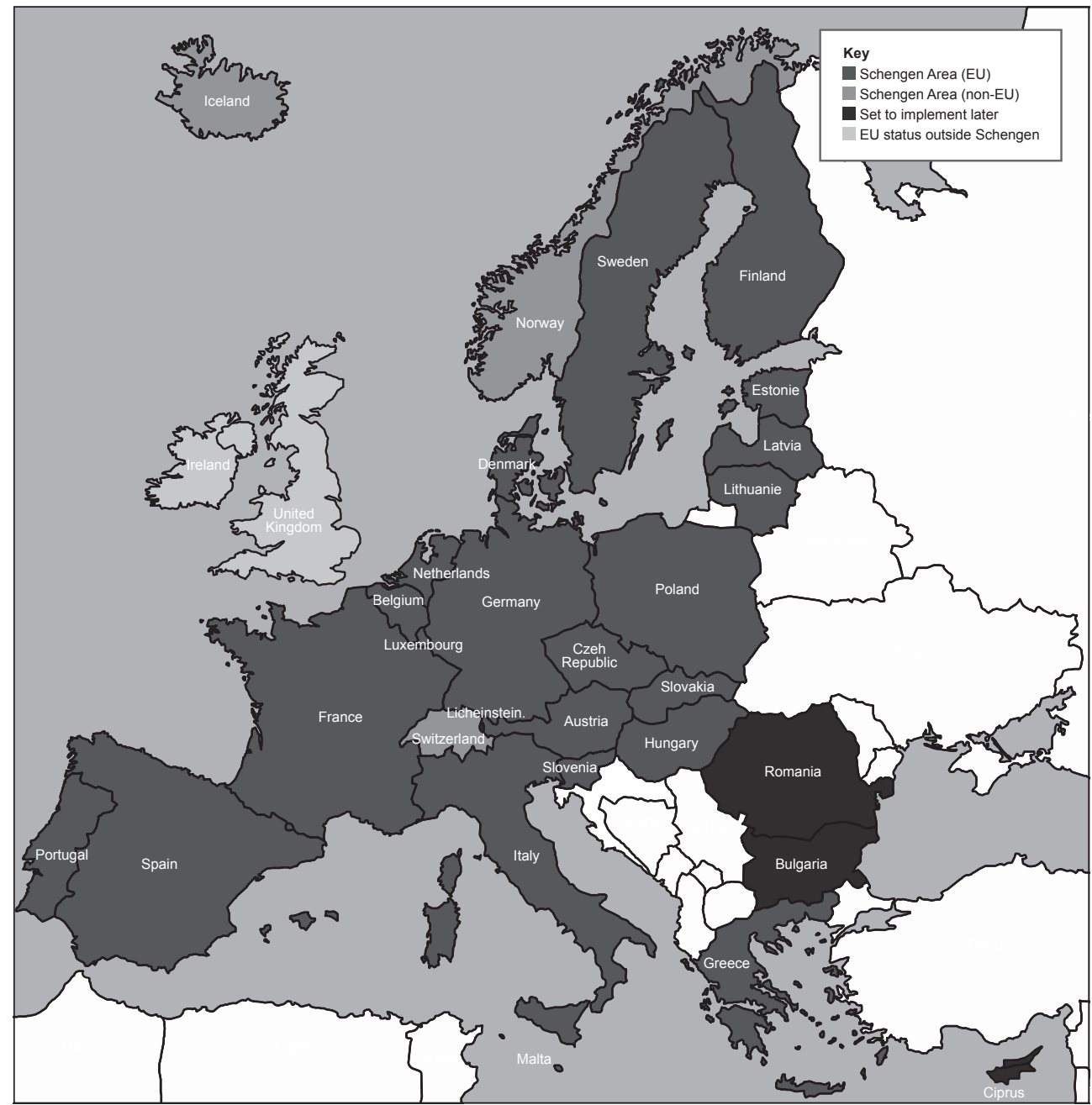

Forrás: http://www.prague-guide.co.uk/the-schengen-zone/

a jugoszláv polgárháború és a boszniai események elól vagy a miatt menekülók jelentkeztek a déli határokon, amelyeket az akkori politikai vezetés, a rendészeti erôk, fóleg a Határôrség kezelni tudott. Késóbb az afgán események miatt jelentkeztek a keleti határokon nagy számban menekültek, migránsok (Kobolka-Ritecz-Sallai, 2003). Közben a schengeni felkészülés idôszakában a rendelkezésre álló eszközök, valamint EU-s támogatások révén modernizálták a Határôrséget, személyállományát fóleg német tapasztalatokra és kapcsolatokra alapozva készítettek fel (Sallai, 1999; Masika-Harmati, 1999).

E folyamat részeként 2004-ben EU, majd 2007. december 21-én Magyarország teljes jogú Schengen-tag lett. Ennek következtében a belsố határokon felszámolták a határforgalom-ellenőrzést, és megerôsítették a külső határok védelmét, felügyeletét. 
2008-tól elsôsorban a világpolitikai események folyamatosan újabb és újabb biztonsági kihívások elé állították a magyar (EU-Schengen) külsố határok ôrzôit (2008-as világválság; válsággócpontok: Irak, Pakisztán, Afganisztán; 2011-es arab tavasz kettős negatív hatása: a védőernyô felszámolása Afrika felôl, illetve a migrációkibocsátó országok részéról katalizátorszerep; elhúzódó szír polgárháború; globális felmelegedés). Az embercsempészés ,jó biznisz”-ként jelentkezett.

A 2015-ben jelentkezô migrációs krízis során, a külsô határon a teljes évben befelé irányuló tiltott határátlépések száma több százezerre növekedett. Ezzel párhuzamosan megnôtt az embercsempészek tevékenysége is. A migrációs hullám addig tartott, amíg Magyarország kormánya le nem zárta a határokat. A magyar-szerb határ kerítéssel történô lezárásának utolsó momentuma volt a Röszke közúti határátkelőhelyen illegálisan bejutni szándékozó személyek elôtt az átjárás lehetôségének felfüggesztése.

6. ábra: Migránsútvonalak Magyarországon: 2015. január 1. - szeptember 15.

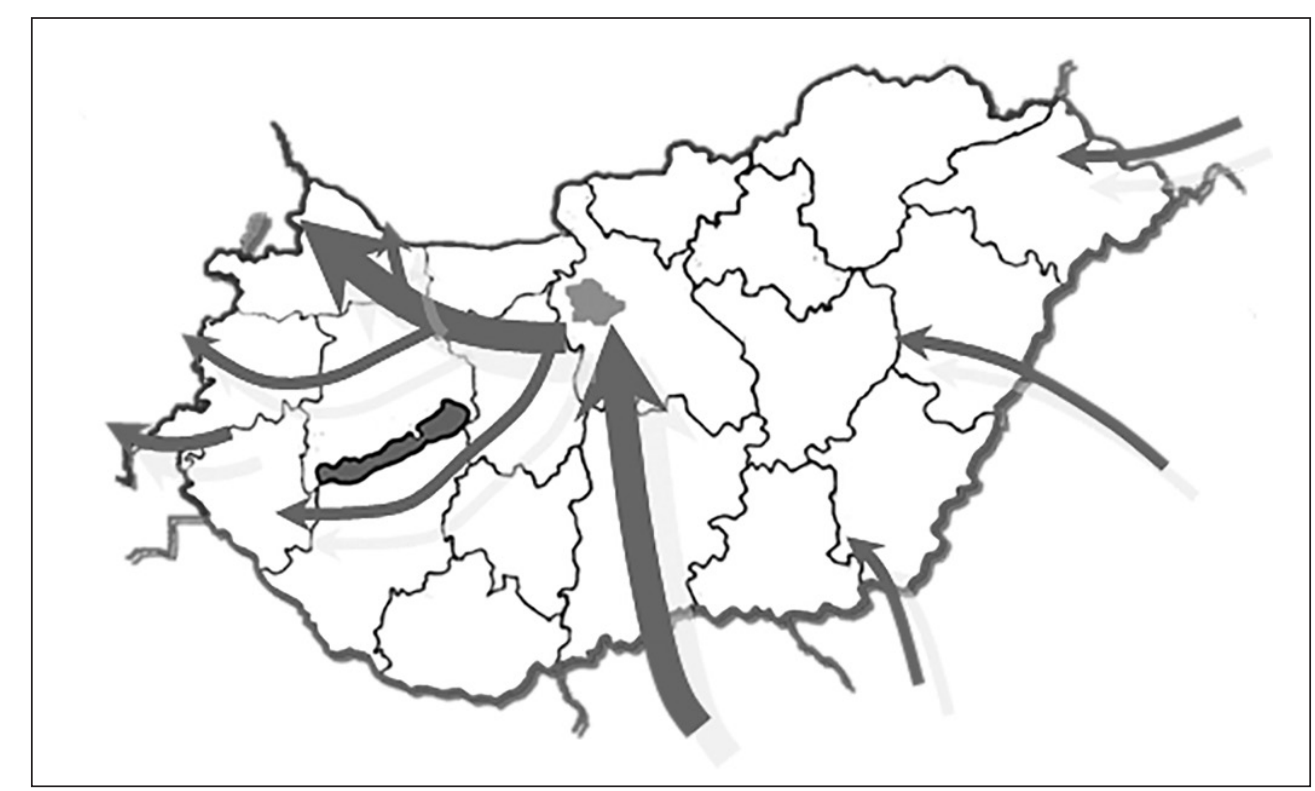

Forrás: Saját szerkesztés

A 6. ábrán látható vastag nyilak a migránsok tömegét és útvonalát jelképezik. Jól látható, hogy a déli magyar-szerb határról belépve, Budapestet érintve, Gyôr-Hegyeshalom térségében hagyták el az országot, és mentek tovább Németországba. A vékonyabb nyilak a délkeleti, keleti, alacsonyabb intenzitású migrációs irányt jelzik. A nagy migrációs nyomásra a magyar kormány a szerb határon² történő „, ideiglenes biztonsági határzár” (IBH), népiesen „kerítés” vagy „vasfüggöny” megépítésével válaszolt, ezért a migrációs nyomás nyugati irányba terelôdött, és új menekülő útvonalat keresett.

Magyarország déli határszakaszán két lépcsôben közel 300 km hosszan épült ideiglenes biztonsági határzár, az elsố sor kerítés felépítése a következô: 
A vertacél oszlopos határzár általános múszaki jellemzôi:

- 2,5-3 méterenként elhelyezett vert oszlopok (az utólag épített szakaszok esetében 5 méterenként);

- vízszintes merevítôk általánosan minden 10. közben, ferde merevítók minden 10. és 11. közben elhelyezve, iránytörésekben két irányban;

- kerítésfonat a magyar oldal felóli síkon elhelyezve, 3 szál 4 mm-es feszítóhuzalon;

- az oszlopok tetején a szerb oldal felé hajló hattyúnyakak készülnek, melyeken 1 szál 3,1 mm-es feszítóhuzal fut;

- a feszítóhuzalon és hattyúnyakakon 1 sor NATO-dróthenger;

- a merevítések rögzítése bekötőlemezzel, helyszíni lőtt szeges megoldással történik;

- gépjármúkapuk 10 kilométerenként, személykapuk 2 kilométerenként;

- a vertacél oszlopos határzár szerb oldalán kiegészítô védelemként a gyorstelepítésû́ határzár szerinti akadály épült.

Gyorstelepítésú határzár:

- 2,5 mm átmérôjú, 3 m hosszú vert betonacél cövekek 5 méterenként;

- 3 sor 3,1 mm feszítóhuzal;

- 3-4 sor NATO-dróthenger egymás felett elhelyezve;

- betonacél cöveken Y magasító a 4. sor pengésdrót felhelyezéséhez;

- személykapuk 2 kilométerenként.

A kerítés szerkezetét földbe vert acéloszlopok adják (C140 profil - 4,5m). Az oszlopok 1,5 méter mélyre leverése speciális cölöpverô gépekkel történik, így a kerítésoszlop magassága 3,0 méter. A fennmaradó 3 méteres szakasz tetejére valamennyi oszlopon hattyúnyakat és pengés dróthengert helyeztek el. A drótháló 3 méter magas, és a lefonása 15 méter hosszúságban történik. A drótháló anyaga 2,5 mm átmérôjú horganyzott acélhuzal. A keresztirányú merevítés C140-es szelvényekből készül, a két végén csomólemezekkel és loott szeges technológiával rögzítve, minden tizedik oszlopközben vagy töréspontonként telepítve.

A kerítésre, a rendôrségi igények szerint, gyalogoskapukat és gépkocsi áthajtására alkalmas kapukat építettek be. A kerítés szerb oldalán betonvas oszlopok állnak egymástól 5 méter távolságra, és ehhez vezetôdrót segítségével rögzítik egymás fölé a 3-4 sor pengésdrótot.

A szerkezeti alapanyagok MSZ EN 10025 szabvány szerinti, S235JR minôségben, az MSZ EN ISO 1461:2000 szabvány szerinti tûzihorgany bevonattal készülnek a korrózió ellen.

A vezérdrótok feszítése GRIPPLE feszítôszemekkel történik. A drótfonatot és a vezérdrótot horganyzott acélfülekkel, lôtt szeges technológiával rögzítették a szerkezeti elemekhez; valamint a drótfonatot RAPID galvanizált kapcsokkal a vezérdróthoz, 30 centiméterenként. A drótfonat és vezérdrót horganyvastagsága $60-80 \mathrm{~g} / \mathrm{m}^{2}$, szakítószilárdsága 450-550N/mm². A NATO-drót BTO-22 szabvány szerinti, préselt acélpengékkel készült (Vájlok, 2016).

A 7. ábrán jól látható, hogy a migráció útvonala a szerb-magyar határról 2015. szeptember 17., a kerítés felépítése után a horvát-magyar határra terelődött. De jelzi azt is, hogy kis létszámban ugyan, de továbbra is próbálkoztak bejutni illegális módon 
7. ábra: Migránsútvonalak Magyarországon 2015. szeptember 17. - október 17.

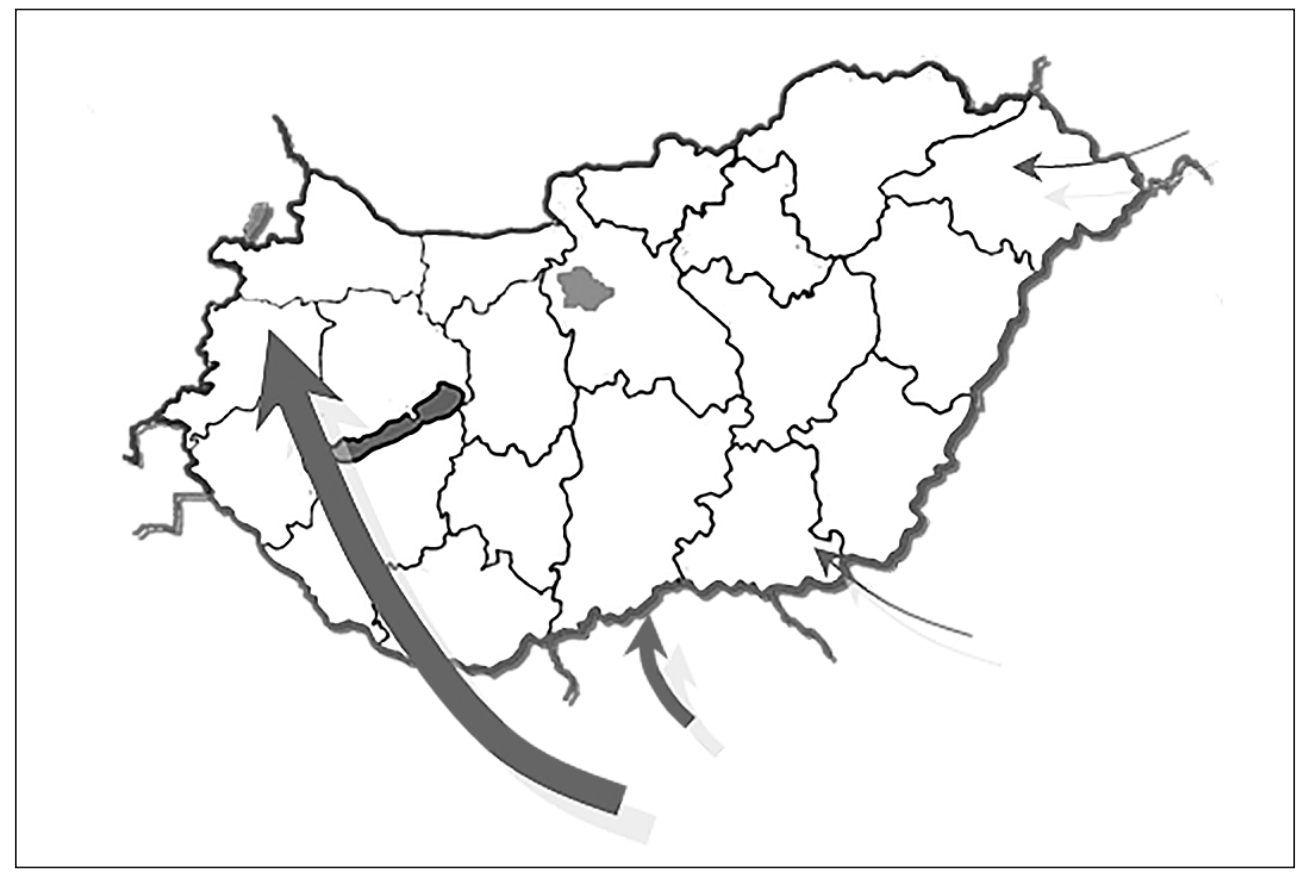

Forrás: Saját szerkesztés

a szerb-magyar határon. Erre a nyomásra a kormány a horvát ${ }^{3}$ határon is megépítette a „kerítést”, ami továbbterelte nyugati irányba a migránsok tömegét, akik Németországba, Nyugat-Európába akartak eljutni. A 8. ábra a horvát határon felhúzott kerítés utáni helyzetet szemlélteti, amelyben jól kirajzolódik a migránsok Szlovénia, Ausztria felé fordulása. Késôbb a határôrizet és a migráció elleni fellépés szigorítása $(8$ km-es zóna bevezetése, mélységi ellenôrzés fokozása) következtében a napjainkat is jellemzó helyzet alakult ki (9. ábra).

Napjainkra a román viszonylat megerôsödött; Szerbiából illegálisan Romániába mennek, és mivel ott nincs kerítésünk, onnan próbálnak meg átjutni Magyarországra. Ehhez kapcsolódik egy nagyon vékony nyíl Horvátország irányából, közvetlenül a Duna kifolyása mentén, ugyanis ebbe az irányba is elindult némi vándorlás Szerbiából Horvátország felé, és onnan az ártéri területen Magyarországra.

Összegezve megállapítható, hogy a migráció elleni fellépés eszköze három nagy pilléren alapul.

Az 1. pillére a múszaki határzár kiépítése szerb és horvát viszonylatban $(155+140$ km-en). Ehhez kapcsolódott viszonylatonként 2-2 tranzitzóna kialakítása, amelynek célja, hogy a külsô határon döntsük el, ki az, aki valóban menekültstátuszra vagy oltalmazásra szorul, és aki nem ilyen, azt tartsuk távol az EU (SCH) térségétôl.

A határőrizet hatékonyságát fejlesztendő, valamint a határőrizetet ellátó állomány komfortérzetét növelô intézkedések körében került sor határôrizeti magasfigyelók és 


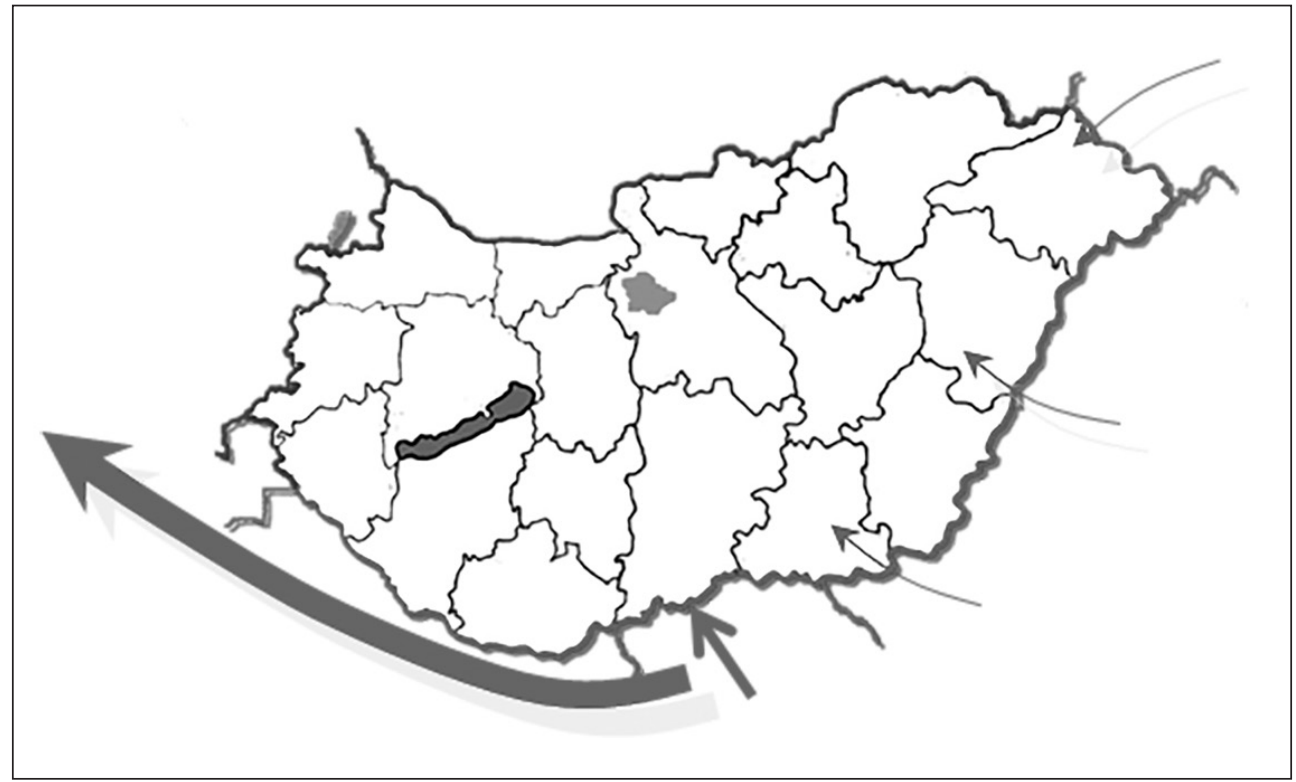

Forrás: Saját szerkesztés

9. ábra: Migránsútvonalak Magyarországon 2017-tôl

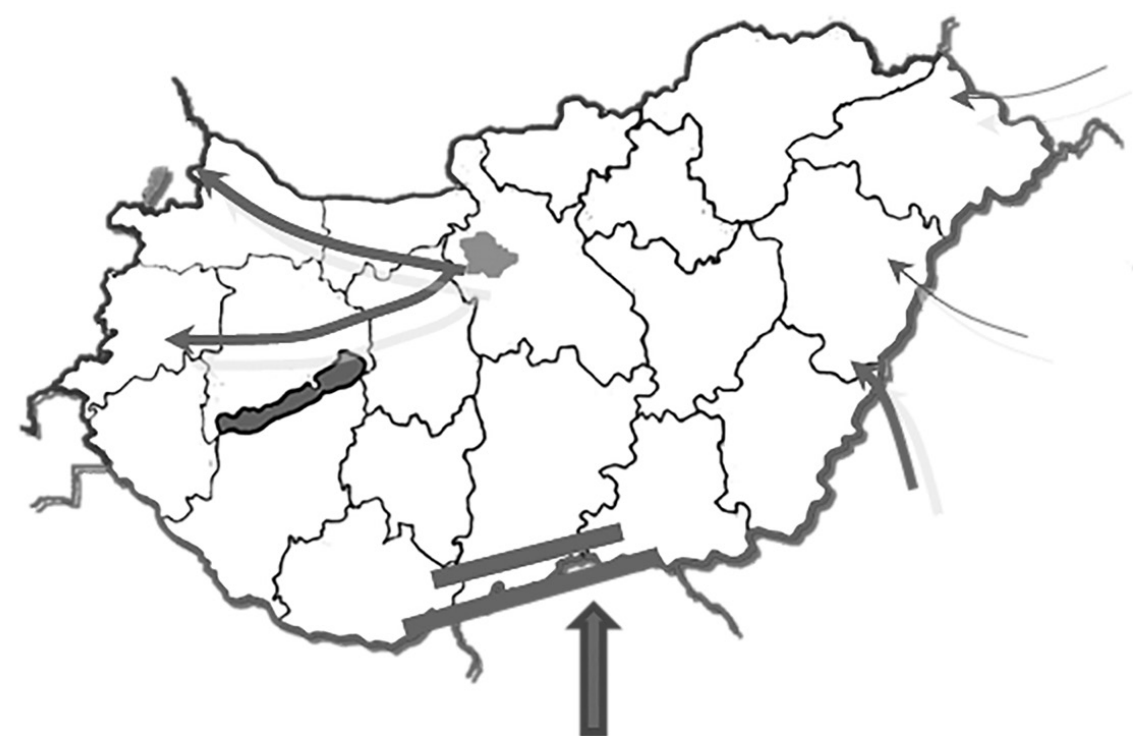

Forrás: Saját szerkesztés 
esőbeállók telepítésére. A teljes magyar-szerb határszakaszon mintegy 158 magasfigyelôt és 127 esôbeállót állítottunk fel. A nyár végén telepített magasfigyelők tekintetében sor került azok szélmentesítési, téliesítési átalakítására is. A téliesítés során szél elleni szigetelőréteget kapott a magasfigyelő oldala, csúszásbiztossá alakították a feljutást biztosító falétrát, valamint a magasfigyelố szél és csapadék elleni védelmet, de láthatóságot is biztosító plexiburkolatot kapott.

Az elektromos áram határszakaszra való eljuttatása több új fejlesztést is lehetôvé tett. Egyrészrôl 2016 tavaszán megkezdôdött egy technikai és elektronikus védelmi rendszer kiépítése a meglévô ideiglenes biztonsági határzáron, amely a teljes határszakaszt folyamatos megfigyelés alatt tartó intelligens (mozgásérzékelô szenzorral ellátott) kamerarendszert, világítást, hangfigyelmeztetést és passzív optikai rezgésérzékelôt tartalmaz. Ennek következtében 193 telepítési helyszínen 297 lézerkamerát és 89 hôkamerát helyeztek el, ezek rendszerbe állítása 2017-ben is folytatódik.

A 2. pillér a megfeleló jogi alapokat biztosítja, így a tömeges bevándorlás okozta válsághelyzet kezelését és kihirdetését, a honvédség alkalmazásának lehetôségét a schengeni határok órizetében, a tranzitzóna kialakítását és alkalmazását, a Büntetô törvénykönyv szigorítását.

A 3. pillér a humán erőforrással való megerôsítést jelentette, így a Határrendészeti Igazgatóság megalakítását, megerôsítô erôk (saját, honvéd vagy külföldi, például visegrádi 4 ország) alkalmazását a határőrizetben.

Ez a hármas egység (technikai, jogi és humán) együttes bevezetése hozta meg az eredményeket.

Ami a földrajzi megközelítést illeti, itt is három zónáról beszélünk.

Az elsố zóna közvetlenül a határterületre fókuszál a határtól 8 km-es sávban.

A második zóna a 8-20 km-es sáv.

A harmadik az ország mélységében lévô teljes terület.

A fenti intézkedések és fejlesztések jelentôs előrelépést jelentenek a hatékony határôrizet végrehajtása érdekében. A hatékonyság egyrészrôl az új technológiáknak köszönhetôen gyorsabb és rugalmasabb reagálást tesznek lehetôvé, másrészt biztosítják majd a legköltségesebb élőerô érezhetô csökkentését is a határon.

A magyar rendészeti szervek számára a legnagyobb gondot az jelentette, hogy nem múködnek a visszafogadási egyezmények, illetve továbbra sem érthetô, hogy Görögországba miért nem lehet visszaküldeni azt, aki ott lépett be elôször az EU területére. Dublini egyezmények nem funkcionálnak. Ráadásul Szerbia sem fogad vissza senkit, így a magyarok oda sem tudnak senkit visszatoloncolni. Ilyen körülmények között Ausztriából pedig addig nem fogadnak senkit vissza, amíg nem bizonyították, hogy Magyarországon lépett elóször az EU területére a külföldi.

\section{MagYarorszÁg VÉdi EuRóPÁt?}

A nemzetközi pénzvilág és a multinacionális gazdasági érdekek érvényesülése nem számol a globális folyamatok következményeivel, ahogy a rákos sejtek terjedését sem gátolja az, hogy a szervezet elpusztulásával ôk is elpusztulnak. 
10. ábra. Asszociatív térkép, amely a világtérképen torzítással emeli ki a szegénységi küszöb (napi 1,25 USD) alatt élö népesség számát

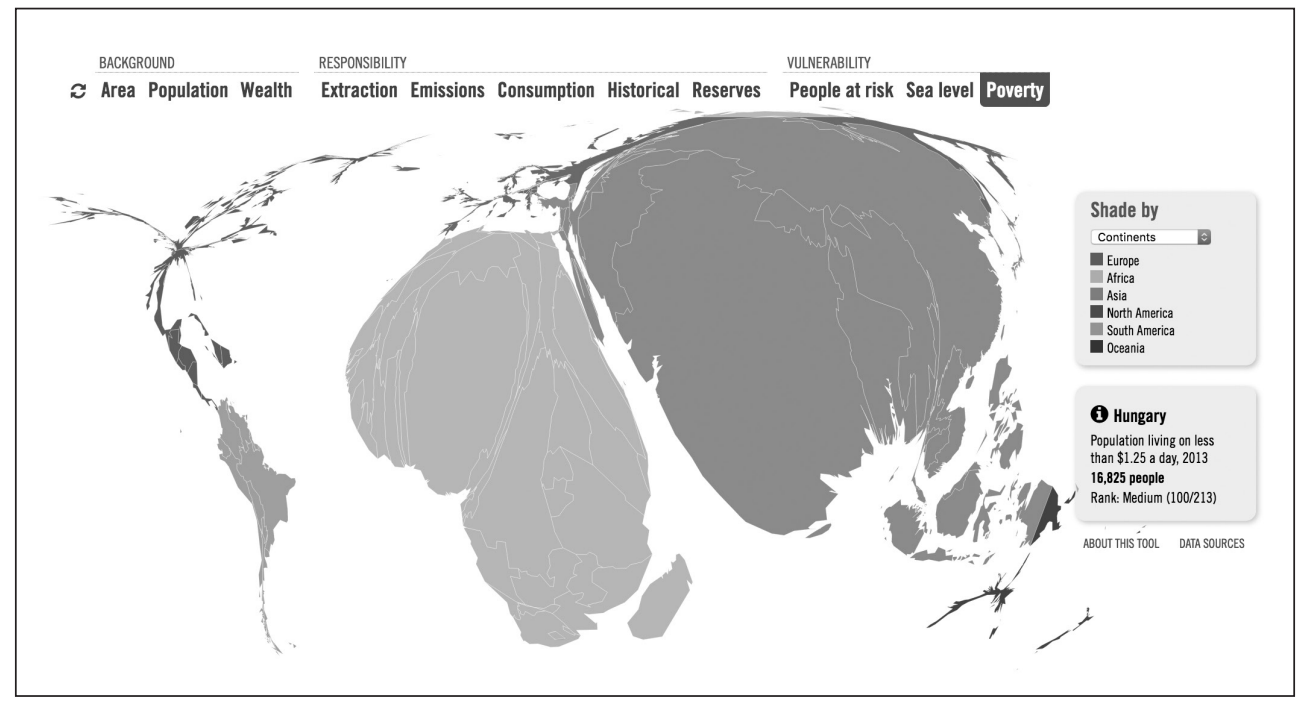

Forrás: http://nagysandor.eu/TED/Greg_Asner.html

A 10. ábra térképe azt ábrázolja, hogy a szegénységi küszöb alatt éló tömegek volumene milyen ijesztố mértékben haladja meg a jóléti társadalmakban - beleértve Oroszországot is - élôk együttes számát! Ennek az ázsiai és afrikai tömegnek nincs mit veszítenie: a médiából látják a jóléti nyugati társadalmak kényelmét és pazarlását; jogosan kérnek ebbôl részt ők is. Ha a szülőföldjükön nem kínálkozik megélhetés számukra, útrakelnek, és nem állítja meg óket sem Törökország hadserege, sem a magyar kerítés.

A 11. ábra azt szemlélteti, hogy mi vonzza a mélyszegénységben éló afrikai, ázsiai lakosságot az USA és Európa felé. Az elfogyasztott termékek, termények és igénybe vett szolgáltatások átszámíthatók az úgynevezett ökológiai lábnyomra, és így összehasonlíthatóvá válnak a jóléti társadalmak és a szegény régiók országai.

Ehhez hasonlóan ábrázolja a 12. ábra a világ nagy regionális különbségeit, amit az egyes országokra vetített GDP fejez ki. Az európai tömbben sötét színnel kiemelt Magyarország nagyságát, gazdasági dimenzióját tekintve jelentéktelen tényezô, és nem alkalmas egy modern kori népvándorlás megakadályozására. Mégis utat mutat az egyetlen olyan irányba, amelyben az európai kultúra fenntartható. Ebben már van felelôssége Oroszországnak is, amely ízig-vérig európai ország, de hatalmas nyersanyag- és energiatartalékokkal rendelkezik Észak-Ázsiában (Szibériában). Mint európai nagyhatalom, ô is felelős azért, hogy Európa megmarad-e európainak - ha már Európa legerósebb gazdasági hatalma, Németország és az Unió, illetve annak gazdaságpolitikai vezetôi feladják az európai pozíciók védelmét. Mert a 10., 11. és 12. ábra vizuálisan kitúnôen szemléltetik, hogy az egyébként is - Észak-Amerikához képest - nagyon nehezen vagy egyáltalán nem védhetô Európa áldozatul esik a globális kiegyenlítődést célzó folyamatoknak. 
11. ábra. Asszociatív térkép, amely a világtérképen torzítással emeli ki a fogyasztás ökológiai lábnyomban kifejezett nagyságát az egyes kontinenseken

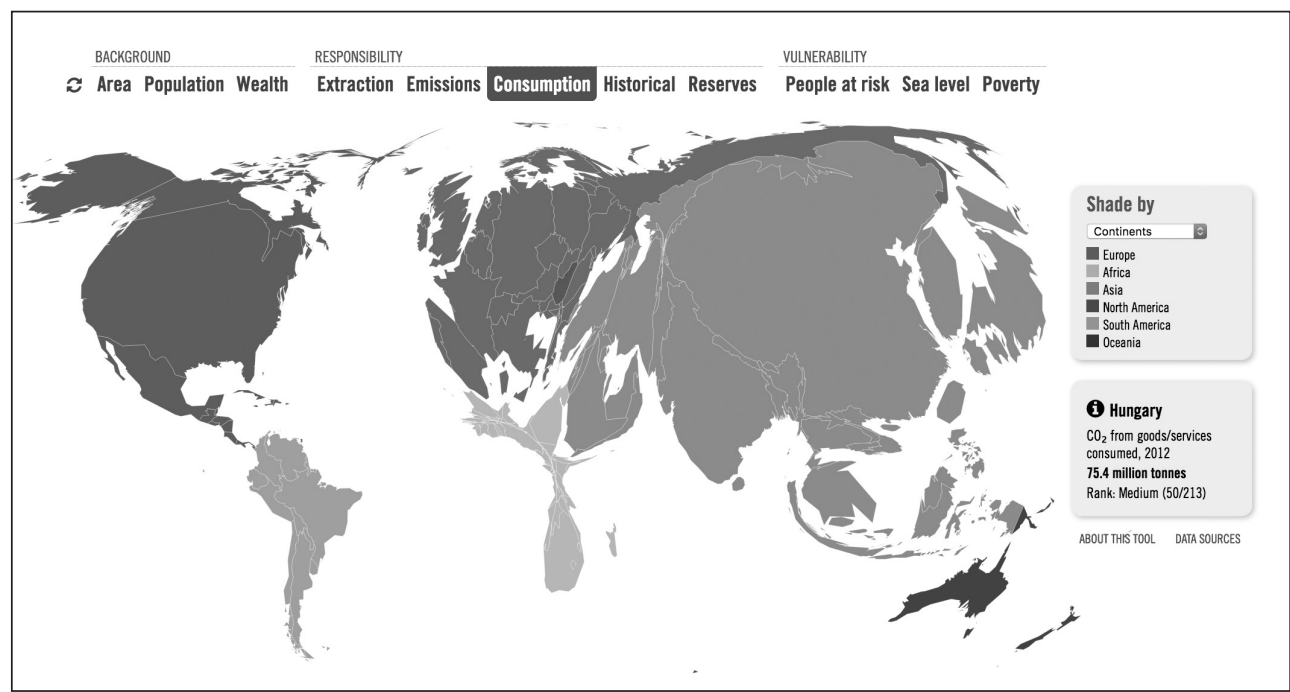

Forrás: http://nagysandor.eu/TED/Greg_Asner.html

12. ábra. Asszociatív térkép, amely a világtérképen torzítással emeli ki az egyes országok gazdasági fejlettségét reprezentálni hivatott GDP-t a kontinenseken

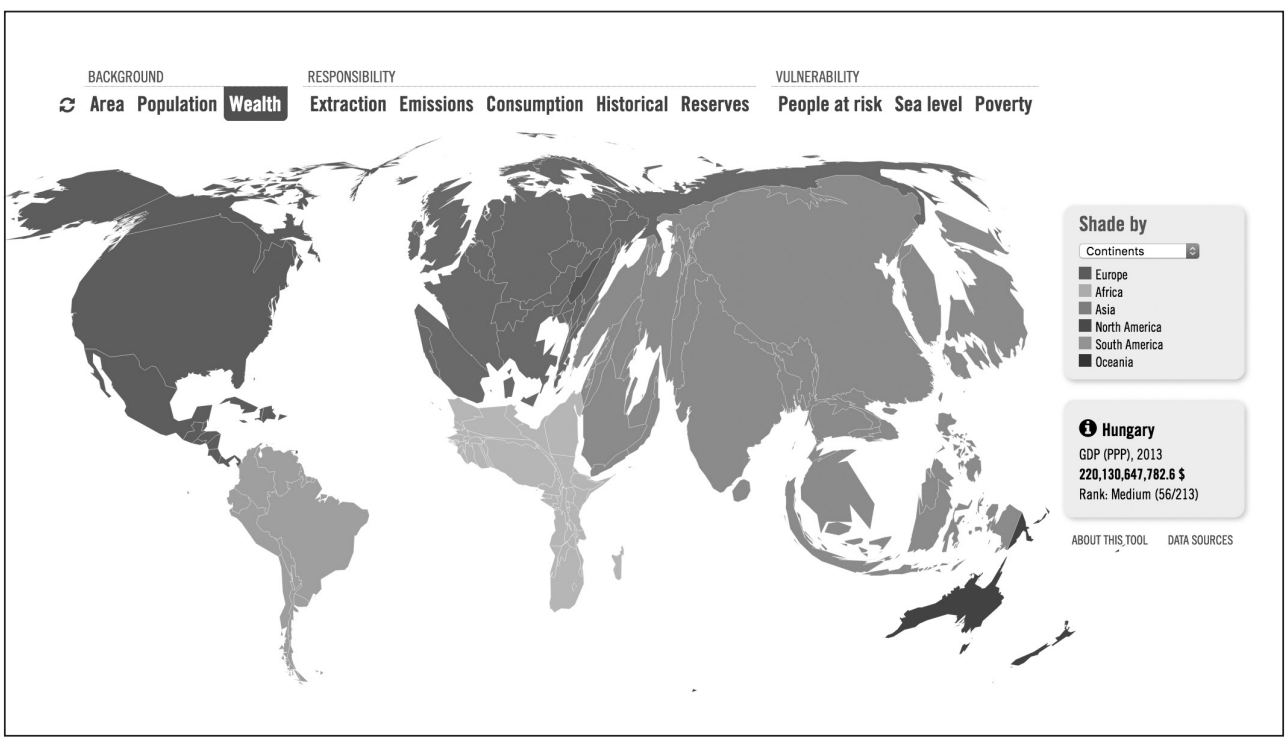

Forrás: http://nagysandor.eu/TED/Greg_Asner.html 


\section{Tózsa István-Sallai János: Geostratégia az EU délkeleti kapujában}

\section{ÖsSZEFOGLALÁS}

Az 5. ábra egyben olyan geostratégiai helyzetet mutat be, amelyrôl világosan látszik, hogy a görög Schengen-tagság elhamarkodott intézkedés volt, Görögország, amint az elmúlt években bebizonyosodott, sok ezer egymáshoz, a kis-ázsiai partokhoz közel fekvố szigetével védhetetlen az illegális migráció esetén. Még az olasz félsziget is jobban védhetô, tekintve, hogy csak több száz kilométeres tengeri úton érkezhetnek illegális bevándorlók. Az Európai Unió délkeleti részének védelme geostratégia szempontjából egyértelmú: Szlovénia, Magyarország. Ilyen tekintetben Románia és Bulgária csak pufferzónát jelenthet. Még ha Horvátország, sốt a távolabbi jövôben esetleg az Unióba belépô Montenegró és Albánia is tagja lenne a schengeni határőrizeti zónának, az Adriai-tenger szigetekkel tarkított partvidéke éppen olyan nehezen kontrollálható lenne, mint Görögországé. A magyar kerítésépítés és sikeres határvédelem tehát nem a múltnak vagy a jelennek, hanem a jövônek épült ki.

\section{JEGYZETEK}

1 More than 400,000 asylum seekers were registered with employment agencies, but only 34,000 got work. (Több mint 400 ezer menedékkérô jelentkezett be a munkaközvetítôknél, de csak 34 ezren álltak munkába.) Kroet, 2016.

2 Szerb határszakasz (163,3km hosszú összefüggố múszaki határzár): Csongrád és Bács-Kiskun megye területén 163,3 km hosszan vertacél oszlopos biztonsági határzár kialakítása történt; természetes akadály (pl. folyó): 11,7 km.

3 Horvát határszakasz (133km hosszú összefüggố szárazföldi mûszaki határzár): Somogy és Zala megye területén összesen $53 \mathrm{~km}$ határzár kialakítása történt; 36 km hosszan gyorstelepítésû drótakadály (GYODA) és vertacél oszlopos határzár; 17 km-es szakaszon csak GYODA épült. Baranya megyében összesen 80,44 km-en létesült határzár: 76,1 km hosszan vertacél oszlopos biztonsági határzár; 4,34 km hosszan csak GYODA épült.

\section{FELHASZNÁLT IRODALOM}

Kobolka István - Ritecz György - Sallai János (2003): A Magyar Köztársaság államhatárának ezredfordulós kriminálföldrajza. Szakmai Szemle, 1. sz., 33-41.

Kroet, Cynthia (2016): Most Migrants in Germany Fail to Get Jobs. Politico, 19 December, www.politico.eu/ article/most-germany-migrants-fail-to-get-jobs-unemployment/.

Masika Edit - Harmati Gergely (1999): Egységes belbiztonsági és jogi térség Európában: bel-és igazságügyi együttmúködés az Európai Unióban. Miniszterelnöki Hivatal Integrációs Stratégiai Munkacsoport, Budapest.

Sallai János (1999): A schengeni egyezmény felépítése, tartalma és végrehajtásának tapasztalatai. Rendvédelmi Füzetek, 5. sz., Rendôrtiszti Főiskola, Budapest.

Sallai János (2001): A Schengeni Egyezmény és a magyar határôrizet. Európai Tükör, 6. évf., 5. sz., 65-100.

Vájlok László (2016): A határbiztonsági rendszer hatékonyságát növelô infrastrukturális, mûszaki és technikai fejlesztések 2016. évben. In: Évkönyv. ORFK Budapest, 1-4. 